\title{
Transoral endoscopic thyroidectomy vestibular approach (TOETVA): Our outcomes from Turkey
}

\author{
Bülent Dinç (D), Mehmet illker Turan² (D), Umut Rıza Gündüz' (D), Nurhan Haluk Belen ${ }^{1}$ (D) \\ ${ }^{1}$ Clinic of General Surgery, Health Sciences University Antalya Training and Research Hospital, Antalya, Turkey \\ ${ }^{2}$ Clinic of General Surgery, Kepez State Hospital, Antalya, Turkey
}

\begin{abstract}
Objective: The Transoral Endoscopic Thyroidectomy Vestibular Approach (TOETVA) was described in 2016 and had its case series published. This study aimed to present the largest TOETVA case series performed in Turkey.

Material and Methods: Data from 52 patients who underwent TOETVA procedure between February 2018 and October 2019 were analyzed retrospectively. Demographic data, duration of operation, blood loss, rate of conversion to open surgery, radiological findings, pathological outcomes, and complications were analyzed.

Results: All patients were female. Mean duration of the operation was $192 \pm 45$ minutes, mean blood loss was $39 \pm 47 \mathrm{~mL}$, and the ratio of surgical site infection was $6 \%(3 / 50)$. In two (4\%) patients, TOETVA was converted to open surgery. Temporary and permanent recurrent laryngeal nerve (RLN) paralysis was observed in 2 (4\%) and 0 patients, respectively. Temporary and permanent hypoparathyroidism was observed in 10 (20\%) and 0 patients, respectively.

Conclusion: TOETVA procedure is the most recently defined NOTES technique for endocrine surgery. In experienced healthcare centers, TOETVA can achieve outcomes similar and even better than the ones obtained with open surgery. The complication rates, durations of operation, surgical site infection, and blood loss parameters that we observed in our experience are similar to the ones reported in the literature.
\end{abstract}

Keywords: Minimally invasive surgery, natural orifice endoscopic surgery, thyroidectomy

Cite this article as: Dinç B, Turan Mi, Gündüz UR, Belen NH Transoral endoscopic thyroidectomy vestibular approach (TOETVA): Our outcomes from Turkey. Turk J Surg 2020; 36 (4): $340-346$

\section{Corresponding Author}

Bülent Dinç

E-mail: bulent1999@yahoo.com

Received: 08.06.2020

Accepted: 25.07 .2020

Available Online Date: 29.12 .2020

() Copyright 2020 by Turkish Surgical Society Available online at www.turkjsurg.com

DOI: $10.47717 /$ turkjsurg.2020.4765

\section{INTRODUCTION}

Thyroid hypertrophy, thyroid nodules, and thyroid cancers are the main diseases that require thyroidectomy worldwide (1). Recognized as the pioneering figure of thyroid surgery, Kocher defined the transcervical approach thyroidectomy for such patients for the first time in 1898 (1). The anterior cervical incision is still being used at most healthcare centers (1). While this approach ensures perfect vision and direct access in the central neck area, it also causes an incision scar on the neck, which has a negative effect on patients' quality of life (2). The frequency of thyroid pathologies is increasing especially in the population of young patients (3). Since external appearance is becoming more important in social life, thyroid surgeons have begun to prefer operations with remote access to the neck area. (3). Foremost among these approaches are the transaxillary approach, the bilateral axillo-breast approach (BABA) and the facelift approach (4-6). However, these techniques force surgeons to make large subcutaneous surgical dissections in order to hide the incision scar. This is because in these types of surgeries, there is, inevitably, a visible scar left by a minimal incision or a concealed incision accompanied by large subcutaneous tissue dissection (7).

The introduction of the natural orifice transluminal endoscopic surgery (NOTES), which is performed through natural body orifices without leaving a scar, was an exciting development for many surgeons $(8,9)$. NOTES techniques developed for thyroid surgery were sublingual and transtracheal approaches. However, these techniques were abandoned due to severe tissue damage, high complication rates, and high rates of conversion to open surgery, as well as surgical difficulties caused by movement restriction in the small surgical site (10-12). Following these develop- 
ments, Anuwong (13) defined the transoral endoscopic thyroidectomy vestibular approach (TOETVA) in 2016, and the transoral endoscopic parathyroidectomy vestibular approach later on. This technique can assist to provide access to both thyroid lobes via minimal subcutaneous dissection, besides offering a better vision as well. Furthermore, it leaves no scars because it is a real NOTES procedure (13).

This study aimed to compare the literature with data from patients who underwent surgery using the TOETVA technique at the general surgery clinic of Kepez State Hospital and the Antalya Training and Research Hospital (Antalya, Turkey).

\section{MATERIAL and METHODS}

\section{Patients}

The records of 52 patients who underwent surgery using the TOETVA procedure at the general surgery clinic of Kepez State Hospital and the Antalya Training and Research Hospital (Antalya, Turkey) between February 2018 and October 2019 were included in the study. The data was evaluated retrospectively. The criteria for patients suitable for TOETVA procedures include the following: 1) Patients with a history of hypertrophic scar and who do not want any scars left on their neck, 2) patients with a long diameter of the thyroid gland less than $10 \mathrm{~cm}, 3$ ) a solid benign thyroid nodule of $\leq 6 \mathrm{~cm}, 4) \mathrm{T} 1$ differentiated thyroid cancer cases confirmed by preoperative imaging that have a solid malign thyroid nodule of $\leq 2 \mathrm{~cm}$ and that lack lateral neck lymph node metastasis or tracheal invasion. Thyroid gland and thyroid nodule diameters were evaluated by ultrasonography. The criteria of the patients unsuitable for TOETVA procedure are: 1) History of a maxillofacial or neck surgery, 2) previous radiotherapy on the head, neck and upper mediastinum, 3) clinically active hyperthyroidism, 4) substernal goiter, 5) proven lateral neck lymph nodule metastasis, 6) suspicion of invasion in adjacent organs such as the esophagus, trachea and recurrent laryngeal nerve (RLN), 7) compromised oral hygiene, 8) unsuitability for general anesthesia, and 9) patients who do not want the procedure to be applied. These criteria have been compiled from the studies conducted by the clinics with high levels of experience with TOETVA (13). All patients were informed about the TOETVA procedure, and written consents were obtained. This study was approved by the institutional review board (IRB) of University of Health Sciences Antalya Training and Research Hospital (IRB number: 02/05/2019-12/22).

The first 30 patients were operated by two surgeons (B.D., M.I.T.). Preoperatively, all patients underwent physical examination; serum parathormone $(\mathrm{PTH})$, serum calcium and thyroid function tests; fine needle aspiration cytology; and thyroid ultrasonography. Patients considered to simultaneously have both parathyroid and thyroid pathology also underwent Tc-99m MIBI parathyroid scintigraphy to detect localization. Patients who previously had treatment on the lower jaw and teeth were sent to have a dental examination, while those who had a previous nasal operation were sent to have otorhinolaryngological examination. In order to avoid postoperative infection and decrease microbial concentrations in the patients, all patients were instructed to mouthwash their mouths with chlorhexidine twice a day three days before the operation.

\section{Surgical Technique}

Nasotracheal or orotracheal intubation with adhesive electrodes was applied in all of the patients under general anesthesia. While the patients were in supine position, a slight extension of the neck was ensured by placing a low pillow under the shoulders. Endotracheal tube and anesthesia equipment were placed on the left corner. Amoxicillin-clavulanic acid was administered at $1.2 \mathrm{~g} 30$ minutes before the incision. In order to protect the eyes and nose, they were covered and closed with textile and Tegaderm film roll (3M Company, Saint Paul, MN, USA). The anterior neck area and the oral cavity were disinfected with $10 \%$ povidone-iodine.

First, a $10 \mathrm{~mm}$-incision was applied through the middle of the vestibulum, and the submandibular site was accessed using a cautery and curved clamp to pass through the jaw. For hydrodissection, diluted adrenaline solution (1:500 000) was used. This solution was injected from the vestibular area toward the frontal side of the neck using a Veress needle; thus, there was constituted subplatysmal a working site. An olive dissector was used to blindly dissect the anterior part of the neck. A $10-\mathrm{mm}$ trocar and $30^{\circ}$ fiberoptic were inserted through the incision. Insufflation was applied to achieve a carbon dioxide $\left(\mathrm{CO}_{2}\right)$ pressure of 6 $\mathrm{mmHg}$. Two 5-mm trocars were inserted in the lateral of the intersection between the canine and first premolar teeth (Figure 1). A working site was created on the subplatysmal area. The upper

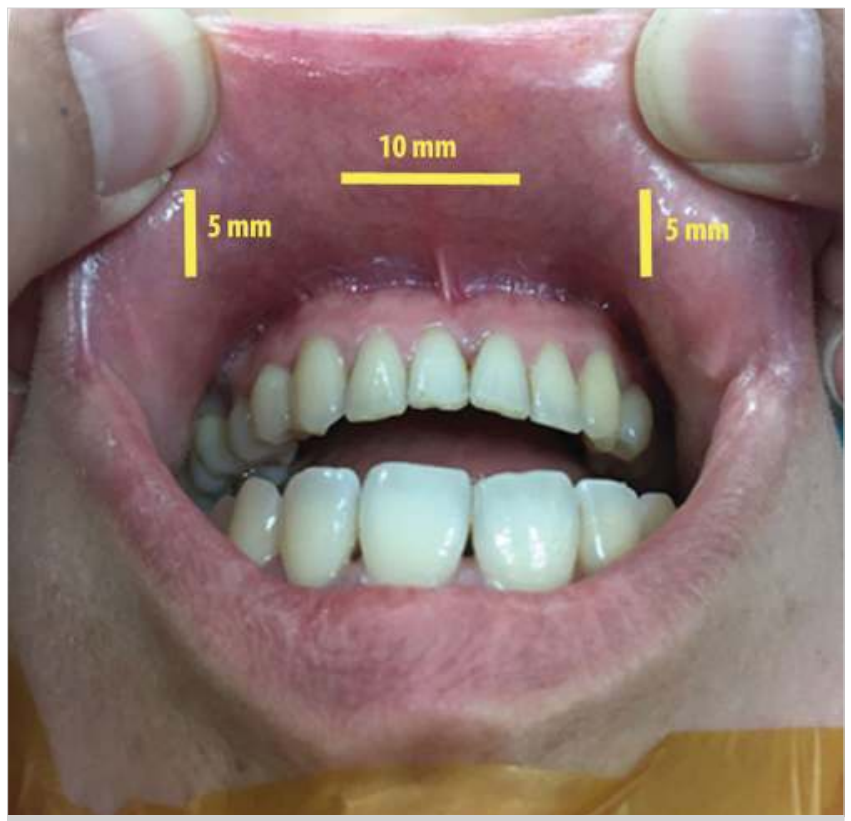

Figure 1. Port placement 
border of this subplatysmal flap was the larynx, its lower border was the suprasternal notch, and its lateral borders were between the anterior edges of the two sternocleidomastoid muscles. This method enabled perfect craniocaudal vision. So as to see the thyroid and trachea, strap muscles were separated from the midline, and retracted toward the lateral sides transcutaneously using 2/0 silk and absorbable synthetic sutures. First, the isthmus of the thyroid was identified, and then, isthmusectomy was completed by dissecting from the trachea. The upper pole vessels were sealed using ultrasonic or bipolar energy devices. For RLN identification and dissection, the gland was retracted to the medial. Intraoperative intermittent neuromonitoring (IONM) was used as a standard in all patients. IONM measurement records were retrieved before and after lobectomy. The dissection was performed in the craniocaudal direction. All parathyroids were identified and spared. Specimens were removed through the 10$\mathrm{mm}$ trocar using an endobag (Figure 2). Linea alba cervicale and in-mouth incision were closed using absorbable sutures. In all of the patients, pressure dressing was applied for 24 hours in a way that covered the jaw and upper area of the neck. Oral intake was initiated on the first postoperative day, and oral antibiotics were prescribed for five days (Figure 3) (14).

\section{Statistical Analysis}

Data were prospectively collected and retrospectively analyzed. All statistical analyses were performed using Statistical Package for the Social Sciences (SPSS) Statistics for Windows, version 21 (IBM Corp., Armonk, N.Y., USA). To describe the basic features of the data, descriptive statistics such as mean, median, standard deviation, and ratio, were used.

\section{RESULTS}

Demographic and clinical data of the patients are presented in Table 1. All patients were female, and median age was 44 years (21-76). Their mean body mass index was $27.1 \pm 4.4 \mathrm{~kg} / \mathrm{m}^{2}$. Preoperative benign pathology was detected in 38 (76\%) of the patients, and 40 (80\%) of these patients underwent total thyroidectomy, while 10 (20\%) underwent hemithyroidectomy. There were 12 (24\%) patients with malignancy or suspicious for malignancy. Of these patients, 11 (91.7\%) underwent total thyroid-
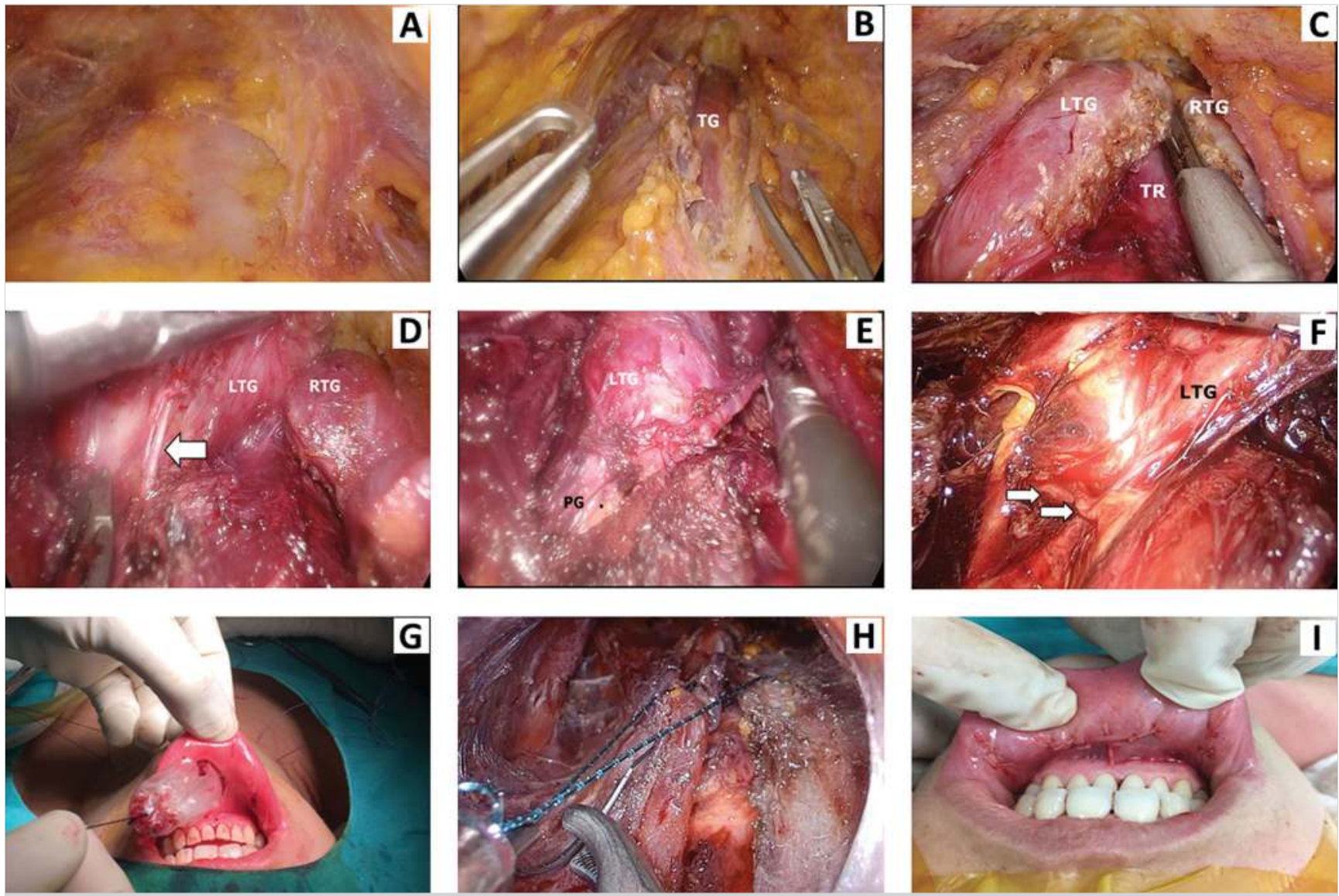

Figure 2. A. Subplatysmal working site; B. Strap muscles being separated in the middle line; C. Isthmectomy; D. Upper pole dissection, external branch of the superior laryngeal nerve (white arrow); E. Upper parathyroid gland; F. Recurrent laryngeal nerve (white arrows); G. Specimens being removed into endobag; $\mathbf{H}$. Closure of strap muscles; I. Closure of port spots.

TG: Thyroid gland, LTG: Left thyroid gland, RTG: Right thyroid gland, TR: Trachea, PG: Parathyroid gland. 

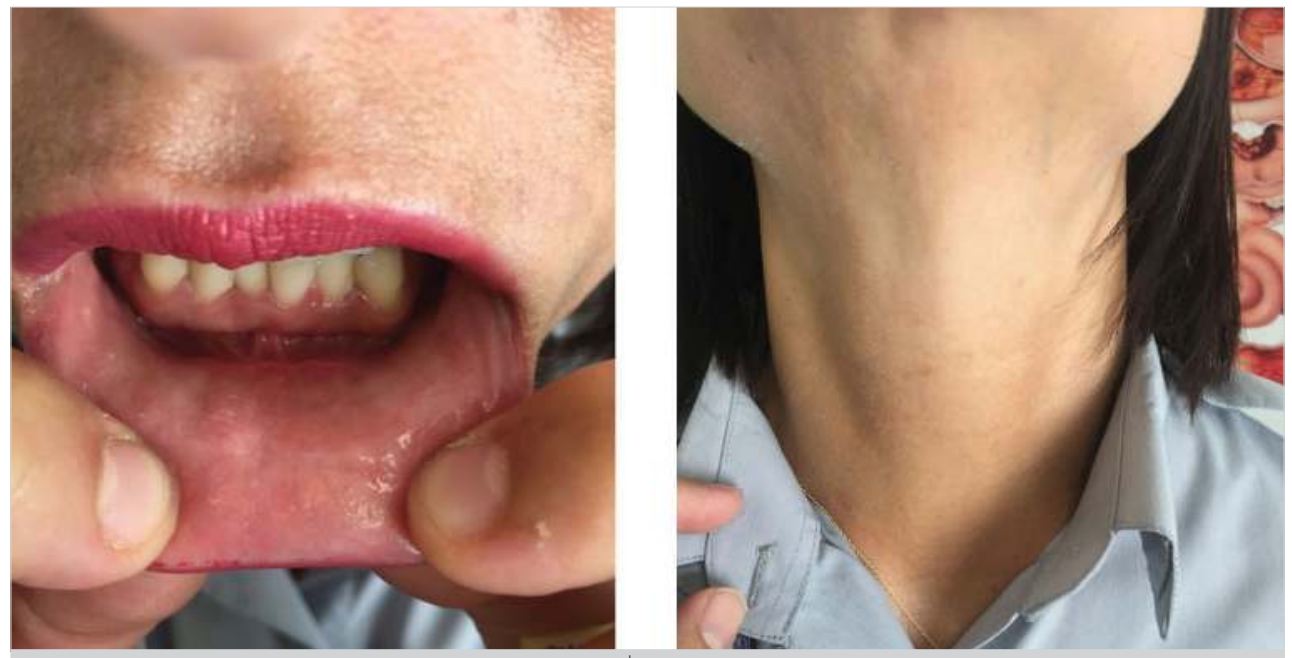

Figure 3. View of the patient in the postoperative $2^{\text {nd }}$ month.

Table 1. Demographic and clinical data

\begin{tabular}{|l|c|}
\hline & $(\mathbf{n = 5 0 )}$ \\
\hline Age, year, median & $44(21-76)$ \\
\hline $\begin{array}{l}\text { Sex } \\
\quad \text { Female } \\
\quad \text { Male }\end{array}$ & $50(100 \%)$ \\
\hline $\begin{array}{l}\text { Preoperative pathology } \mathrm{n}(\%) \\
\quad \text { Bening } \\
\quad \text { Malignant/suspected }\end{array}$ & - \\
\hline Dominant nodule diameter, cm, mean (SD) & $38(76 \%)$ \\
\hline Body mass index, $\mathrm{kg} / \mathrm{m}^{2}$, mean (SD) & $12(24 \%)$ \\
\hline
\end{tabular}

ectomy, whereas 1 (8.3\%) underwent hemithyroidectomy. Two (4\%) patients were converted to open surgery due to serious adhesions. These patients were excluded from the assessment. Total duration of the operation was $192 \pm 45$ minutes. Malignancy related to the thyroid gland was reported in 21 (42\%) of the patients. There was no need for complementary surgery in any of the patients (Table 2).

Nasal bleeding caused by nasotracheal intubation was intraoperatively observed in two of the patients, and the bleeding was taken under control with nasal tamponade. Flap perforation was observed in two patients, which was repaired through reconstruction. Blood loss of over $50 \mathrm{~mL}$ was observed in two of the patients, and hemostasis in these patients was ensured using 5-mm clips in addition to energy devices. There are some complications in TOETVA, such as mental nerve injury and subcutaneous-mediastinal emphysema that were different from those in open thyroid surgery. These complications can negatively affect the quality of life. However, these complications were not observed in our case series. Surgical site infection was observed in 3 (6\%) patients. They were treated with oral antibiotic therapy, and they did not require hospitalization. Tempo- rary unilateral RLN paralysis was postoperatively observed in 2 (4\%) patients, and these patients spontaneously recovered in two weeks. On the other hand, none of the patients showed bilateral or permanent RLN damage. Temporary hypoparathyroidism was detected in 10 (20\%) of the patients. None of the patients showed permanent hypoparathyroidism (Table 2).

\section{DISCUSSION}

After the first endoscopic parathyroidectomy had been performed by Gagner in 1996 (15), different endoscopic methods (axillary, breast areola, retro-auricular, anterior chest approach, etc.) were defined for benign thyroid nodules and certain differentiated thyroid cancers $(16,17)$. Transaxillary thyroidectomy and BABA are frequently practiced in Eastern countries, where a scar on the neck area is considered undesirable $(4,5)$. Although extracervical total endoscopic approaches are viewed as minimally invasive methods, they are also criticized for requiring large subcutaneous dissection and leaving scars on the areas outside the neck (18). With the introduction of the NOTES technique for the first time in thyroid surgery, it became possible to apply procedures that left no scars (11). However, differences in their insertion places and the complications that occurred led surgeons to search for more ergonomic, reliable and effective procedures. The TOETVA procedure was developed as a result of this pursuit (19). TOETVA has proven to be successful and reliable in experimental studies on animals and cadavers (18).

Contrary to the clean scar in open thyroid surgery, the surgeries performed in the oral cavity are classified as clean-contaminated scars. Although the rate of surgical site infection in open thyroid surgery is $0.1 \%-2 \%$, in surgeries performed in the oral cavity, it can rise to $12 \%(19,20)$. To avoid this, it is recommended to use an antiseptic mouthwash started preoperatively, along with prophylaxis that covers gram-positive and anaerobic bacteria. (18). In our study, surgical site infection developed in 3 (6\%) of 
Table 2. Operative data, postoperative data and complications

\begin{tabular}{|c|c|}
\hline & $(n=50)$ \\
\hline $\begin{array}{l}\text { Operation, } \mathrm{n}(\%) \\
\text { Hemithyroidectomy } \\
\text { Total thyroidectomy }\end{array}$ & $\begin{array}{l}10(20 \%) \\
40(80 \%)\end{array}$ \\
\hline $\begin{array}{l}\text { Operation duration, minute, mean (SD) } \\
\text { Hemithyroidectomy } \\
\text { Total thyroidectomy } \\
\text { Total duration }\end{array}$ & $\begin{array}{l}141(25) \\
205(40) \\
192(45)\end{array}$ \\
\hline Blood loss, mL, mean (SD) & $39(47)$ \\
\hline Transition to open surgery, $\mathrm{n}(\%)$ & $2(3.3 \%)$ \\
\hline Hospitalization, day, mean (SD) & $1.6(0.5)$ \\
\hline $\begin{array}{l}\text { Thyroid pathology, n (\%) } \\
\text { Benign } \\
\text { Micropapillary thyroid cancer } \\
\text { Papillary thyroid cancer } \\
\text { Medullary thyroid cancer } \\
\text { Hurthle cell carcinoma }\end{array}$ & $\begin{array}{r}29(58 \%) \\
7(14 \%) \\
12(24 \%) \\
1(2 \%) \\
1(2 \%)\end{array}$ \\
\hline Complications n (\%) & \\
\hline $\begin{array}{l}\text { RLN paralysis } \\
\text { Temporary } \\
\text { Permanent }\end{array}$ & $\begin{array}{c}2(4 \%) \\
0\end{array}$ \\
\hline $\begin{array}{l}\text { Hypoparathyroidism } \\
\text { Temporary } \\
\text { Permanent }\end{array}$ & $\begin{array}{c}10(20 \%) \\
0\end{array}$ \\
\hline Hematoma & 0 \\
\hline Seroma & $3(6 \%)$ \\
\hline Infection & $3(6 \%)$ \\
\hline Intra-operative hemorrhage & $2(4 \%)$ \\
\hline Nasal bleeding & $2(4 \%)$ \\
\hline Flap ischemia/perforation & $2(4 \%)$ \\
\hline Mental nerve injury & 0 \\
\hline Subcutaneous/mediastinal emphysema & 0 \\
\hline Tracheal injury & 0 \\
\hline Esophageal injury & 0 \\
\hline
\end{tabular}

the patients, and our surgical site infection rate is compatible with the literature.

Mental nerve damage occurring in up to $87 \%$ of extra-vestibular transoral thyroidectomy methods has obliged surgeons to use approaches that ensure access through the anterior of mandibular (21). In the vestibular approach defined by Nokaja et al. (22) that involves a $2.5 \mathrm{~cm}$ incision (transoral video-assisted neck surgery (TOVANS), mental nerve damage that lasted for more than six months was observed in all of the eight patients. Wang et al. (23) replaced the port that is in the middle of vestibulum with a $10-\mathrm{mm}$ port, brought it closer to buccogingival sulcus, and placed the two 5-mm ports to the lateral as much as possible. Although there is information in the study regarding pares- thaesia on the gonion, it was necessary to change the insertion spots of the ports, since the 5-mm ports passed through the mental nerve line. Finally, in the TOETVA approach performed by Anuwong (19) in 2016, the 5-mm lateral ports were brought closer to the edge of the lower lips, and mental nerve damage was reported in none of the 60 patients. In our study, no mental nerve damage observed in any of the 50 patients that underwent the TOETVA method defined by Anuwong.

Complications caused by $\mathrm{CO}_{2}$ insufflation, such as massive subcutaneous emphysema and hypercarbia, have been observed in high intracavitary pressures (24). While studies conducted on humans report that pressures under $10 \mathrm{mmHg}$ are reliable, the TOETVA procedure uses a pressure of $6 \mathrm{mmHg}(19,25)$. Another complication caused by insuflattion is $\mathrm{CO}_{2}$ embolism associated with venous injuries that remain open. In a case report published in the literature, Kim et al. (26) injured the anterior jugular vein during the preparation of the skin flap. Because $\mathrm{CO}_{2}$ in the working site entered into the opened vein, $\mathrm{CO}_{2}$ embolism was occurred. In our study, none of the patients developed any complications caused by $\mathrm{CO}_{2}$ insufflation.

Another complication of endoscopic and open thyroidectomy is RLN injury. In open surgery, temporary RLN injury varies between 2 and 12\%, while permanent injuries vary between 0.2 and $6 \%$ (19). Endoscopic minimally invasive thyroidectomy (eMIT) and TOVANS, which are two endoscopic thyroidectomy approaches, have been reported to have RLN injury rates of $25 \%$ and $12.5 \%$, respectively $(21,22)$. In the 200 patients on which Anuwong et al. performed TOETVA procedure, the rate of temporary RLN paralysis was $2.6 \%$, while permanent paralysis was not seen in any of these patients (14). In our study, temporary RLN paralysis was observed in 2 (4\%) patients, while RLN paralysis was not seen in any of the patients. This result is compatible with the literature. Although many studies demonstrating that the use of IONM will be beneficial in reducing RLN paralysis have been published, these studies have included small numbers of cases (27).

According to the literature, the prevalence of temporary and permanent hypoparathyroidism in open surgery is from $0.3 \%$ to $49 \%$ and from $0 \%$ to $13 \%$, respectively $(28,29)$. On the other hand, in TOETVA, temporary hypoparathyroidism has been observed in two (3.3\%) of the 60 patients in the study by Anuwong (19) and in one (6.6\%) of the 15 patients in the study by Dionigi et al. (18). Permanent hypoparathyroidism has been identified in neither one of these two studies. In our study, temporary hypoparathyroidism was detected in 10 (20\%) patients, while permanent hypoparathyroidism was detected in none of the patients. In our opinion, the reason for the high rate of temporary hypoparathyroidism is that this was our first experience.

The present study has some limitations. One of these is the type of study; as it is a retrospective study, this might lead to case selection and assessment bias. Second, the sample size included 
in our study was small. Third, outcomes of the referred studies might differ from those of our study owing to causes such as patient selection, sample size, and variations in regional treatment guidelines. Additionally, there were few published articles on TOETVA. Therefore, the average values of previous studies still do not have a standard value and the outcomes of the literature are heterogenic.

\section{CONCLUSION}

TOETVA is the most recent NOTES technique defined for thyroid surgery. Since the large majority of the patients are young females, it is very important in terms of both cosmetics and psychology that no scar is left on their neck. Because this procedure is a sensitive surgical procedure performed on a limited dissection site, it requires a high level of endoscopic surgical experience. We observed complication rates that were similar to, and even lower, than those in open surgery. These results support the view that this method can be safely applied.

Ethics Committee Approval: The approval for this study was obtained from Antalya Local Ethics Committee for Clinical Research (Decision No: 12/22, Date: 02.05.2019).

Peer-review: Externally peer-reviewed.

Author Contributions: Concept - B.D.; Design - B.D., M.I.T.; Supervision B.D., M.I.T., U.R.G., N.H.B.; Data Collection and/or Processing - B.D., M.I.T., U.R.G., N.H.B.; Analysis and/or Interpretation - B.D., U.R.G.; Literature Review - B.D.; Writing Manuscript - B.D.; Critical Reviews - B.D., M.I.T., U.R.G., N.H.B.

Conflict of Interest: All authors declare that they have no competing interests.

Financial Disclosure: No financial support was used for this study.

\section{REFERENCES}

1. Scerrino G, Inviati A, Di Giovanni S, Paladino NC, Di Paola V, Re GL, et al. Esophageal motility changes after thyroidectomy; possible associations with postoperative voice and swallowing disorders: preliminary results. Otolaryngol Head Neck Surg 2013; 148: 926-32. [CrossRef]

2. Razavi CR, Russell JO. Indications and contraindications to transoral thyroidectomy. Ann Thyroid 2017; 2: 1922-2013. [CrossRef]

3. Berber E, Bernet V, Fahey TJ, Kebebew E, Shaha A, Stack BC, et al. American Thyroid Association Statement on remote-access thyroid surgery. Thyroid 2016; 26: 331-7. [CrossRef]

4. Yoon JH, Park CH, Chung WOY. Gasless endoscopic thyroidectomy via an axillary approach: Experience of 30 cases. Surg Laparosc Endosc Percutaneous Tech 2006; 16: 226-31. [CrossRef]

5. Choe JH, Kim SW, Chung KW, Park KS, Han W, Noh DY, et al. Endoscopic thyroidectomy using a new bilateral axillo-breast approach. World J Surg 2007; 31:601-6. [CrossRef]

6. Terris DJ, Singer MC, Seybt MW. Robotic facelift thyroidectomy: Patient selection and technical considerations. Surg Laparosc Endosc Percutaneous Tech 2011;21:237-42. [CrossRef]

7. Bärlehner E, Benhidjeb T. Cervical scarless endoscopic thyroidectomy: Axillo-bilateral-breast approach (ABBA). Surg Endosc Other Interv Tech 2008; 22: 154-57. [CrossRef]
8. Rattner D, Kalloo A. ASGE/SAGES Working group on natural orifice translumenal endoscopic surgery. Surg Endosc 2006; 20: 329-33. [CrossRef]

9. Clark MP, Qayed ES, Kooby DA, Maithel SK, Willingham FF. Natural orifice translumenal endoscopic surgery in humans: a review. Minim Invasive Surg 2012; 2012: 1-8. [CrossRef]

10. Witzel K, Von Rahden BHA, Kaminski C, Stein HJ. Transoral access for endoscopic thyroid resection. Surg Endosc Other Interv Tech 2008; 22: 1871-5. [CrossRef]

11. Benhidjeb T, Wilhelm T, Harlaar J, Kleinrensink GJ, Schneider TAJ, Stark M. Natural orifice surgery on thyroid gland: totally transoral video-assisted thyroidectomy (TOVAT): report of first experimental results of a new surgical method. Surg Endosc 2009; 23: 1119-20. [CrossRef]

12. Liu E, Qadir Khan A, Niu J, Xu Z, Peng C. Natural orifice total transtracheal endoscopic thyroidectomy surgery: first reported experiment. J Laparoendosc Adv Surg Tech A 2015; 25: 586-91. [CrossRef]

13. Anuwong A, Ketwong K, Jitpratoom P, Sasanakietkul T, Duh QY. Safety and outcomes of the transoral endoscopic thyroidectomy vestibular approach. JAMA Surg 2018; 153:21-7. [CrossRef]

14. Anuwong A, Sasanakietkul T, Jitpratoom P, Ketwong K, Kim HY, Dionigi $G$, et al. Transoral endoscopic thyroidectomy vestibular approach (TOETVA): indications, techniques and results. Surg Endosc 2018; 32: 45665. [CrossRef]

15. Gagner M. Endoscopic subtotal parathyroidectomy in patients with primary hyperparathyroidism. Br J Surg 1996; 83: 875. [CrossRef]

16. Li ZY, Wang P, Wang Y, XU SM, Cao LP, Que RS. Endoscopic thyroidectomy via breast approach for patients with Graves' disease. World J Surg 2010; 34: 2228-32. [CrossRef]

17. Lee KE, Kim HY, Park WS, Choe JH, Kwon MR, Oh SK, et al. Postauricular and axillary approach endoscopic neck surgery: a new technique. World J Surg 2009; 33: 767-72. [CrossRef]

18. Dionigi G, Bacuzzi A, Lavazza M, Inversini D, Boni L, Rausei S, et al. Transoral endoscopic thyroidectomy: preliminary experience in Italy. Updates Surg 2017; 69:225-34. [CrossRef]

19. Anuwong A. Transoral endoscopic thyroidectomy vestibular approach: a series of the first 60 human cases. World J Surg 2016; 40: 491-7. [CrossRef]

20. Dionigi G, Rovera F, Boni L, Castano P, Dionigi R. Surgical Site Infections after thyroidectomy. Surg Infect 2006; 7: S117-20. [CrossRef]

21. Wilhelm T, Metzig A. Endoscopic minimally invasive thyroidectomy (eMIT): A prospective proof-of-concept study in humans. World J Surg 2011; 35: 543-51. [CrossRef]

22. Nakajo A, Arima H, Hirata M, Mizoguchi T, Kijima Y, Mori S, et al. Transoral video-assisted neck surgery (TOVANS). A new transoral technique of endoscopic thyroidectomy with gasless premandible approach. Surg Endosc 2013: 27: 1105-10. [CrossRef]

23. Wang C, Zhai H, Liu W, Li J, Yang J, Hu Y, et al. Thyroidectomy: a novel endoscopic oral vestibular approach. Surg 2014; 155: 33-8. [CrossRef]

24. Gottlieb A, Sprung J, Zheng XM, Gagner M. Massive subcutaneous emphysema and severe hypercarbia in a patient during endoscopic transcervical parathyroidectomy using carbon dioxide insufflation. Anesth Analg 1997; 84: 1154-6. [CrossRef]

25. Kim HY, Choi YJ, Yu HN, Yoon SZ. Optimal carbon dioxide insufflation pressure during robot-assisted thyroidectomy in patients with various benign and malignant thyroid diseases. World J Surg Oncol 2012; 10: 1-7. [CrossRef] 
26. Kim KN, Lee DW, Kim JY, Han KH, Tae K. Carbon dioxide embolism during transoral robotic thyroidectomy: a case report. Head Neck 2018, 40: E25-8. [CrossRef]

27. Dionigi G, Bacuzzi A, Lavazza M, Inversini D, Pappalardo V, Boni L, et al. Transoral endoscopic thyroidectomy via vestibular approach: operative steps and video. Gland Surg 2016: 5: 625-7. [CrossRef]
28. Wiseman JE, Mossanen M, Ituarte PHG, Bath JMT, Yeh MW. An algorithm informed by the parathyroid hormone level reduces hypocalcemic complications of thyroidectomy. World J Surg 2010; 34: 532-7. [CrossRef]

29. Makay O, Unalp O, Icoz G, Akyildiz M, Yetkin E. Completion thyroidectomy for thyroid cancer. Acta Chir Belg 2006; 106: 528-31. [CrossRef]

\section{ORIJINAL ÇALIŞMA-ÖZET}

Turk J Surg 2020; 36 (4): 340-346

\section{Vestibüler yaklaşımlı transoral endoskopik tiroidektomi}

Bülent Dinç ${ }^{1}$, Mehmet Illker Turan², Umut Rıza Gündüz ${ }^{1}$, Nurhan Haluk Belen ${ }^{1}$

Sağlık Bilimleri Üniversitesi Antalya Eğitim ve Araştırma Hastanesi, Genel Cerrahi Kliniği, Antalya, Türkiye

2 Kepez Devlet Hastanesi, Genel Cerrahi Kliniği, Antalya, Türkiye

\section{ÖZET}

Giriş ve Amaç: Vestibüler yaklaşımlı transoral endoskopik tiroidektomi (TOETVA) 2016 yılında tanımlanmış ve vaka serileri yayınlanmıștır. Bu çalışmada amacımız Türkiye'de gerçekleştirilen en büyük TOETVA vaka serisini sunmaktır.

Gereç ve Yöntem: Şubat 2018 ile Ekim 2019 arasında TOETVA işlemi uygulanan 52 hastanın verileri retrospektif olarak incelendi. Demografik veriler, operasyon süresi, kan kaybı, açık cerrahiye dönüşüm oranı, radyolojik bulgular, patolojik sonuçlar ve komplikasyonlar analiz edildi.

Bulgular: Hastaların tamamı kadındı. Ortalama operasyon süresi $192 \pm 45$ dakika, ortalama kan kaybı $39 \pm 47 \mathrm{~mL}$ ve cerrahi alan enfeksiyon oran $\% 6$ (3/50) 'ydı. İki hastada (\%4) açık cerrahiye dönüş yapıldı. Geçici ve kalıcı rekürren laringeal sinir (RLN) paralizisi sırası ile 2 (\%4) ve 0 hastada gözlendi. Geçici ve kalıcı hipoparatiroidizm sırası ile 10 (\%20) ve 0 hastada gözlendi.

Sonuç: TOETVA işlemi endokrin cerrahisi için en son tanımlanan NOTES tekniğidir. Deneyimli sağlık merkezlerinde, açık cerrahi ile elde edilenlere benzer ve hatta daha iyi sonuçlar elde edilebilir. Deneyimlerimizde gözlemlediğimiz komplikasyon oranları, ameliyat süreleri, cerrahi alan enfeksiyonu ve kan kaybı parametreleri literatürle benzerdir.

Anahtar Kelimeler: Minimal invaziv cerrahi, doğal açıklık endoskopik cerrahi, tiroidektomi

Doi: $10.47717 /$ turkjsurg.2020.4765 